\title{
Glypican 4, a Membrane Binding Protein for Bactericidal/Permeability-Increasing Protein Signaling Pathways in Retinal Pigment Epithelial Cells
}

\section{Citation}

Geraldes, Pedro, Michiko Yamagata, Susan L. Rook, Yukio Sassa, Ronald C. Ma, Allen Clermont, Benbo Gao, Lloyd Paul Aiello, Edward P. Feener, and George L. King. 2007. Glypican 4, a Membrane Binding Protein for Bactericidal/Permeability-Increasing Protein Signaling Pathways in Retinal Pigment Epithelial Cells. Invest. Ophthalmol. Vis. Sci. 48, no. 12: 5750. doi:10.1167/ iovs.07-0470.

\section{Published Version}

doi:10.1167/iovs.07-0470

\section{Permanent link}

http://nrs.harvard.edu/urn-3:HUL.InstRepos:33776275

\section{Terms of Use}

This article was downloaded from Harvard University's DASH repository, and is made available under the terms and conditions applicable to Other Posted Material, as set forth at http:// nrs.harvard.edu/urn-3:HUL.InstRepos:dash.current.terms-of-use\#LAA

\section{Share Your Story}

The Harvard community has made this article openly available.

Please share how this access benefits you. Submit a story.

\section{Accessibility}




\title{
Glypican 4, a Membrane Binding Protein for Bactericidal/Permeability-Increasing Protein Signaling Pathways in Retinal Pigment Epithelial Cells
}

\author{
Pedro Geraldes, ${ }^{1}$ Michiko Yamagata, ${ }^{1}$ Susan L. Rook, ${ }^{1}$ Yukio Sassa, ${ }^{1}$ Ronald C. Ma, ${ }^{1}$ \\ Allen Clermont, ${ }^{1,2}$ Benbo Gao, ${ }^{1}$ Lloyd Paul Aiello, ${ }^{1,2,3}$ Edward P. Feener, ${ }^{1,4}$ and \\ George L. King ${ }^{1,4}$
}

Purpose. Originally identified as a lipopolysaccharide binding protein with Gram-negative bactericidal activity in the leukocytes, bactericidal/permeability-increasing protein (BPI) has been shown to induce various effects in retinal cells in vivo and in vitro.

Methods. The authors recently reported that BPI can induce ERK1/2 and Akt activity and that it increases DNA synthesis in the bovine retinal pigment epithelial (RPE) and pericyte cells. The authors have extended the characterization of BPI interaction with membrane proteins from bovine RPE. Crude membrane pools from RPE were isolated, solubilized, and bound to $\mathrm{rBPI}_{21}$ affinity column. Bound proteins were separated by SDSPAGE and stained with Coomassie blue, which showed an intense band at $36 \mathrm{kDa}$ consistently displaced by $\mathrm{rBPI}_{21}$.

Results. Tandem mass spectrometry of the $36-\mathrm{kDa}$ band suggested that cell surface protein glypican 4 (GPC4) serves as a putative BPI-binding protein. Heparitinase, phosphatidylinositol-specific phospholipase C, and anti-GPC4 antibody suppressed BPI-induced ERK and Akt phosphorylation in bovine RPE. Moreover, heparitinase also inhibited BPI actions on VEGF and PDGF-B mRNA expression induced by $\mathrm{H}_{2} \mathrm{O}_{2}$.

Conclusions. These new findings suggest that GPC4 is a specific binding protein for BPI on RPE to mediate the activation of ERK1/2, Akt, and the mRNA expressions of PDGF-B and VEGF. (Invest Ophthalmol Vis Sci. 2007;48:5750-5755) DOI: 10.1167/iovs.07-0470

$\mathrm{O}^{\prime}$ riginally identified as a lipopolysaccharide (LPS) binding protein with specific Gram-negative bactericidal activity released from the azurophilic granules of neutrophils, ${ }^{1,2}$ bactericidal/permeability-increasing protein (BPI) is known to be expressed in a variety of cell types such as epithelial cells in the trachea and the gut. ${ }^{3}$ Recently, our group has demonstrated that BPI mRNA levels can also be detected in bovine retina,

From the ${ }^{1}$ Research Division and ${ }^{2}$ Beetham Eye Institute, Joslin Diabetes Center; and the Departments of ${ }^{4}$ Medicine and ${ }^{3}$ Ophthalmology, Harvard Medical School, Boston, Massachusetts.

Supported by a grant from XOMA, Inc. (GLK), American Diabetes Association Research Grant 1-95-RA-61 (GLK), and the Diabetes and Endocrinology Research Center at Joslin Diabetes Center, which is funded by National Institutes of Health Grant P30 DK36836.

Submitted for publication April 19, 2007; revised July 26, 2007; accepted October 8, 2007

Disclosure: P. Geraldes, None; M. Yamagata, None; S.L. Rook, None; Y. Sassa, None; R.C. Ma, None; A. Clermont, None; B. Gao, None; L.P. Aiello, None; E.P. Feener, None; G.L. King, None

The publication costs of this article were defrayed in part by page charge payment. This article must therefore be marked "advertisement" in accordance with 18 U.S.C. $\$ 1734$ solely to indicate this fact

Corresponding author: George L. King, Research Division, Joslin Diabetes Center, One Joslin Place, Boston, MA 02215;

george.king@joslin.harvard.edu. retinal pigment epithelial (RPE), and primary cultures of bovine RPE (BRPE) cells, pericytes, and endothelial cells. ${ }^{4}$ Several recent reports showed that BPI has multiple antiangiogenic effects, such as inducing apoptosis in human umbilical veinderived endothelial cells and inhibiting angiogenesis in chorioallantoic membrane. ${ }^{5}$ The human recombinant $21-\mathrm{kDa}$ modified amino-terminal fragment of BPI $\left(\mathrm{rBPI}_{21}\right)$ retained the bactericidal and LPS binding activity at equivalent or greater potency than the holoprotein. ${ }^{6,7}$ Interestingly, we reported that $\mathrm{rBPI}_{21}$ can also promote bovine pericyte and BRPE growth and can paradoxically suppress vascular endothelial growth factor (VEGF)-induced mitogenic actions in BRPE cells. ${ }^{8}$

In diseases such as retinopathy of prematurity and proliferative diabetic retinopathy, the major cellular abnormalities include the selective loss or apoptosis of retinal capillary pericytes and RPE cells and the subsequent development of new blood vessels in hemorrhage and retinal detachment. ${ }^{9,10}$ VEGF, a potent endothelial cell mitogen and angiogenic factor, is crucial for normal and important pathologic angiogenesis. VEGF is strongly and preferentially induced by hypoxia and oxidants in RPE cells. ${ }^{11}$ Platelet-derived growth factor (PDGF)-B is also critically involved in the recruitment of pericytes to a variety of vascular beds such as brain, kidney, heart, lung, retina, and adipose tissue. ${ }^{12}$ Animal model studies involving genetic or pharmacologic inhibition of PDGF-B mRNA/ PDGF-B receptor pathway have demonstrated that the resultant pericyte deficiency is sufficient to trigger states of retinopathy that are similar to nonproliferative diabetic retinopathy. ${ }^{13}$ This insight regarding PDGF-B mRNA suggests that the induction of angiogenesis in the retina requires not only an elevation of VEGF but may be enhanced by a decrease in PDGF action. ${ }^{14}$ The degeneration of RPE also may result in decreases in the production of pigment epithelial-derived factor and PDGF. This would permit the choriocapillaris to respond to endogenous tissue growth factors and to invade the RPE cell layer, including the macula, causing degeneration of the retina and loss of visual function.

We have recently reported that BPI is endogenously expressed in epithelial and vascular cells in the retina and that it can induce biological actions on microvascular cells to decrease hypoxia-induced angiogenesis and VEGF- or diabetesinduced permeability in the retina. ${ }^{4}$ To investigate further the mechanistic actions of BPI, we characterized the binding properties by which BPI could influence its cellular signaling actions in BRPE.

\section{MATERIALS AND Methods}

\section{Cells}

Fresh calf eyes were obtained from a local abattoir. Primary cultures of BRPE were isolated by homogenization and a series of filtration steps, as described previously. ${ }^{15}$ Briefly, cells were isolated by gentle scraping after removal of the neural retina and incubation with $0.2 \%$ colla- 
genase. ${ }^{16}$ BRPE cells were subsequently propagated in Dulbecco modified Eagle medium (DMEM) with $5.5 \mathrm{mM}$ glucose and $10 \%$ fetal bovine serum (FBS; Gibco BRL, Grand Island, NY). Cells were cultured in 5\% $\mathrm{CO}_{2}$ at $37^{\circ} \mathrm{C}$, and media were changed every other day. The authenticity of BRPE was verified by the presence of pigment granules on transmission electron microscopy. ${ }^{16}$ BRPEs from passages 2 through 5 were used in these experiments. Cells remained morphologically unchanged under these conditions, as confirmed by light microscopy.

\section{Reagents}

$\mathrm{rBPI}_{21}$, a 21-kDa human recombinant modified, amino-terminal fragment of BPI, was provided by XOMA (Berkeley, CA). ${ }^{17} \mathrm{rBPI}_{21}$ preparations were tested in rabbit pyrogen assay, and no endotoxin was detected. Heat-inactivated $\mathrm{rBPI}_{21}$ was made by boiling at $100^{\circ} \mathrm{C}$ for 4 hours. Materials were obtained from commercial sources, as follows: primary antibodies for immunoblotting, including anti-phospho-Akt, total-Akt, phospho-p44/42, and total-ERK from Cell Signaling (Beverly, MA); phosphatidylinositol-specific phospholipase C from Sigma (St. Louis, MO); sodium heparin from Elkins-sinn (Cherry Hill, NJ); tropicamide from Alcon Laboratories (Fort Worth, TX); activated media (Affi-Gel 10) from Bio-Rad Laboratories (Hercules, CA); heparitinase from Seikagaku Corporation (Tokyo, Japan) and from Sigma. Antiglypican 4 antibody was a generous gift from Dr. M. Ford-Perris (Department of Anatomy and Cell Biology, University of Melbourne, Parkville, Victoria, Australia). ${ }^{18}$

\section{Immunoblot Analysis}

Cells were stimulated with the compounds indicated after overnight starvation in $0.1 \%$ BSA. Cells were lysed in Laemmli buffer $(50 \mathrm{mM}$ Tris [pH 6.8], 2\% SDS, and 10\% glycerol) containing protease inhibitors (1 $\mathrm{mM}$ phenylmethylsulfonyl fluoride, $2 \mu \mathrm{g} / \mathrm{mL}$ aprotinin, $10 \mu \mathrm{g} / \mathrm{mL}$ leupeptin, $1 \mathrm{mM} \mathrm{Na} \mathrm{VO}_{4}$; Sigma). Samples were separated by SDS-PAGE, transferred to nitrocellulose membrane, and blocked with 5\% skim milk. Antigens were detected using horseradish peroxidase-linked surface protein (Protein A; Amersham Biosciences, Freiburg, Germany) for Western blotting with anti-GPC4 antibody or anti-rabbit horseradish peroxidase-conjugated antibody for other Western blotting and detected with the enhanced chemiluminescence (ECL) system (Amersham Biosciences).

\section{Real-Time PCR Analysis}

Real-time PCR was performed to evaluate mRNA expressions of VEGF and PDGF-B in cultured BRPE. Total RNA was extracted from cultured cells with reagent (Tri-Reagent; Invitrogen, Carlsbad, CA), as described by the manufacturer and treated with DNAse I (DNAse I; Invitrogen) to remove any genomic DNA contamination. Approximately $1 \mu \mathrm{g}$ RNA was used to generate cDNA using reverse transcriptase and random hexamers (SuperScript II; Invitrogen) at $42^{\circ} \mathrm{C}$ for 60 minutes. PCR primers and probes were as follows: bovine VEGF (GenBank NM 174216), forward 5'-CCATCACAGAACAATCCTGAA-3', reverse 5'TGCGCACAGCCTCCTCTT- 3 ', probe 5'6FAM-CAGAAACCTGACATGAAG-TAMRA3'; bovine PDGF-B mRNA (GenBank NM 001017953), forward 5'-GAGAGTGTGGGCAGGGTTATTT-3', reverse 5'-GGGAACAATATAATCACTCCAAGGA-3', probe 5'6FAM- TATGGTATTTGCTGTATTGCCCCCATGG-TAMRA3'. 18S ribosomal RNA expression was used for normalization. PCR products were gel purified, subcloned (QIA Quick PCR Purification kit; Qiagen, Valencia, CA), and sequenced in both directions to confirm identity.

\section{Isolation of BPI Binding Protein}

Ten milligrams BBPI $_{21}$ was dialyzed against HEPES buffer $(0.1 \%$ HEPES [pH 8.0]). Activated media (Affi-Gel 10, $1 \mathrm{~mL}$; Bio-Rad Laboratories) was washed with 3 vol deionized water and subsequently mixed with the $\mathrm{rBPI}_{21}$ solution. After shaking the mixture overnight at $4^{\circ} \mathrm{C}$, the gel was washed and subsequently equilibrated with PBS. BRPE were scraped, washed, and homogenized by douncing for 50 strokes in hypotonic lysis buffer (20 mM Tris [pH 7.4], $2 \mathrm{mM}$ EDTA, $0.5 \mathrm{mM}$ EGTA, $1 \mathrm{mM}$ dithiothreitol, $0.1 \mathrm{mg} / \mathrm{mL}$ aprotinin). After centrifugation at $1000 \mathrm{~g}$ for 5 minutes, the supernatant was centrifuged at $100,000 \mathrm{~g}$ for 30 minutes in a rotor (70.1TI; Beckman, Hialeah, FL). The pellet containing crude plasma membrane fraction (including mitochondrial membrane and endoplasmic reticulum) was resuspended in Laemmli buffer. Two milligrams resuspended pellet was incubated with and without $20 \mu \mathrm{g} \mathrm{rBPI}_{21}$ or heat-inactivated $\mathrm{rBPI}_{21}$ overnight at $4^{\circ} \mathrm{C}$ and then with $100 \mu \mathrm{L}$ activated media (Affi-Gel 10, $1 \mathrm{~mL}$; Bio-Rad Laboratories) coupled with $\mathrm{rBPI}_{21}$ overnight at $4^{\circ} \mathrm{C}$. Proteins were eluted with Laemmli buffer, separated by SDS-PAGE, and stained with Coomassie blue.

\section{Tandem Mass Spectrometry}

Gel slices were digested with trypsin (Promega, Madison, WI) and analyzed by capillary liquid chromatography, nanospray ionization, and tandem mass spectroscopy (MS) using a two-dimensional linear ion trap mass spectrometer (LTQ; Thermo Finnigan, Hemel Hempstead, Hertfordshire, UK). Data acquisition was carried out using a sequence of full-scan MS (range, 400-1200 m/z) followed by 10 data-dependent $\mathrm{MS}^{2}$ events. Assignment of $\mathrm{MS}^{2}$ data was performed using the nonredundant (nr) protein database from the National Center for Biotechnology Information and from Thermo Finnigan (TurboSequest; BioWorks 3.1). Variable posttranslational modifications were made based on the following criteria: cross-correlation score (Xcorr) greater than $1.5,2.0$, and 2.5 for charge states $+1,+2$, and +3 , respectively; $\mathrm{dCN}$ (Delta Correlation) greater than 0.1 ; Sp (Primary Score) greater than 500; Rsp (ranking of the primary score), 1 ; and percentage of fragment ions greater than $30 \%$. Proteins were identified when two or more unique peptides were matched.

\section{Statistical Analysis}

Differences among groups with normal distribution and equal variance were analyzed using unpaired Student's $t$-tests. ANOVA with Tukey test was used for multiple comparisons of data with equal variance and normal distribution. $P<0.05$ was considered statistically significant.

\section{Results}

\section{Identification of Membrane BPI-Binding Protein}

Because $\mathrm{rBPI}_{21}$ rapidly induced ERK phosphorylation, we speculated that there could be BPI binding proteins or receptors on the surface of BRPE. To identify this molecule, the membrane fraction derived from BRPE was fractionated using affinity chromatography on an immobilized $\mathrm{rBPI}_{21}$ column. Proteins were eluted from the gel separated by SDS-PAGE and stained with Coomassie blue. Analysis of crude preparation of membrane protein binding to immobilized $\mathrm{rBPI}_{21}$ suggested a 36$\mathrm{kDa}$ band with more intense Coomassie blue staining in the samples without BPI or with heat-inactivated $\mathrm{rBPI}_{21}$ than the membrane protein fraction that was preincubated with excess free $\mathrm{rBPI}_{21}$ (Fig. 1A). The band at $36 \mathrm{kDa}$ was excised from the gel and digested with trypsin, and the resultant peptide fragments were analyzed by liquid chromatography coupled to tandem mass spectrometry (LC-MS/MS). Analysis of MS/MS spectra (TurboSequest; Thermo Scientific, Waltham, MA) revealed that this band contained a mixture of proteins, only one of which was a protein known to exist on the cell surface, termed glypican 4 (GPC4) (Fig. 1B). The band size is smaller than the expected size of $67 \mathrm{kDa}$. However, previous reports have shown that various bands including a $32-$ to $36-\mathrm{kDa}$ fragment are observed by Western blotting of GPC4. ${ }^{1819,20}$ Thus, GPC4 detected at $36 \mathrm{kDa}$ is identified as a potential candidate for BPI binding protein. 
A)

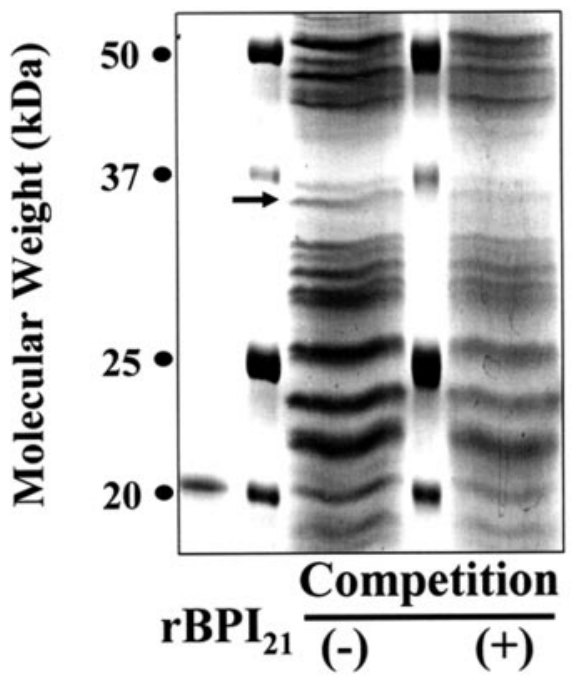

B)

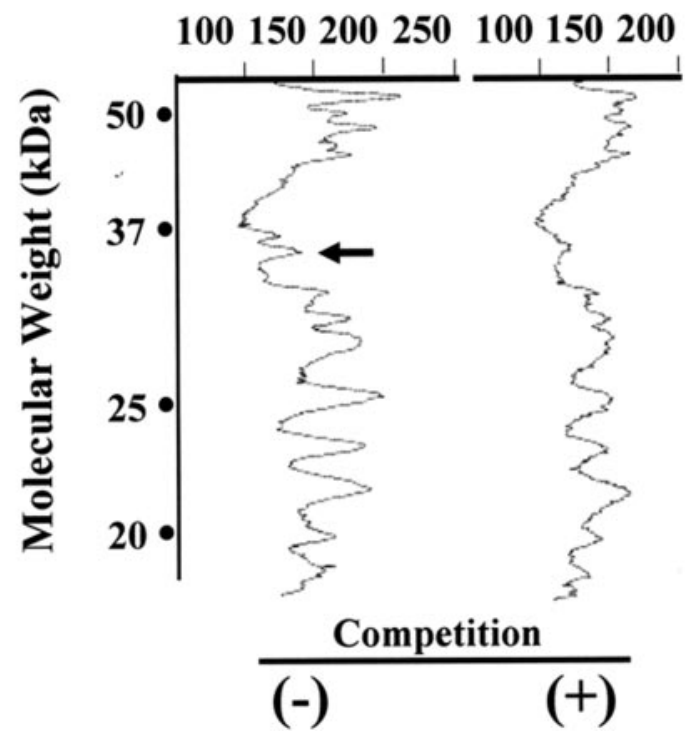

FIGURE 1. BPI membrane-binding protein identification by LC-MS/MS BRPE crude membrane proteins, with and without $\mathrm{rBPI}_{21}$ preincubation, were separated by SDS-PAGE (A). Area quantitation was performed $(\mathbf{B})$, and the area of each band was normalized by the total area. The area of the $36-\mathrm{kDa}$ band (arrowhead) was most decreased after preincubation with excess free $\mathrm{rBPI}_{21}$, analyzed with LC-MS/MS after in-gel tryptic digests for sequencing and database searching, and identified as GPC4. These studies were performed twice.

\section{Reduction of PBPI $_{21}$-Induced Akt and ERK Phosphorylation in BRPE by Heparitinase}

Glypicans are glycosylphosphatidylinositol (GPI)-anchored heparan sulfate proteoglycans that are expressed on the cell surface. ${ }^{21}$ Thus, if GPC4 is a BPI binding protein, heparitinase treatment, which specifically cleaves heparan sulfate chains, should disrupt BPI binding to GPC4 and impede signal transduction. BPI-induced Akt phosphorylation was reduced by $72 \%$ and $78 \%$ at $0.5 \mu \mathrm{M}$ and $1 \mu \mathrm{MrBP}_{21}(P=0.031$ and $P<0.001)$, respectively (Fig. 2A). Preincubating BRPE cells with heparitinase also reduced $\mathrm{rBPI}_{21}$-induced ERK phosphorylation by $54 \%$
$(P=0.059)$ and $83 \%(P=0.018)$ at $0.1 \mu \mathrm{M}$ and $0.5 \mu \mathrm{M} \mathrm{rBPI}_{21}$, respectively (Fig. 2B).

\section{Heparitinase Prevents rBPI ${ }_{21}$ Effects on VEGF and PDGF-B mRNA Expression}

It is well known that overexpression of VEGF and oxidative stress in retina are the main pathologic mechanisms of retinopathy of prematurity (ROP). ${ }^{4}$ We previously demonstrated that $\mathrm{rBPI}_{21}$ can suppress retinal neovascularization in the murine model of retinopathy. Therefore, to evaluate the potential mechanism related to this inhibitory action of $\mathrm{rBPI}_{21}$, we measured the effect of $\mathrm{rBPI}_{21}$ on the expressions of VEGF and PDGF-B mRNA induced by $\mathrm{H}_{2} \mathrm{O}_{2}$. VEGF mRNA expression was increased after a 4-hour incubation with $\mathrm{H}_{2} \mathrm{O}_{2}(100 \mu \mathrm{M})$ by 3.5-fold ( $P<0.05$; Fig. 3A). Coincubation with $\mathrm{rBPI}_{21}(1 \mu \mathrm{M})$ reduced by $70 \%$ the mRNA expression of VEGF induced by $\mathrm{H}_{2} \mathrm{O}_{2}(P<0.05)$. These effects of $\mathrm{rBPI}_{21}$ were blocked when cells were pretreated with a dose-dependent effect of heparitinase with maximum inhibition at $0.04 \mathrm{U} / \mathrm{mL}(P<0.05$; Fig. $3 \mathrm{~A})$. Addition of $\mathrm{rBPI}_{21}$ alone reduced VEGF mRNA expression

A)

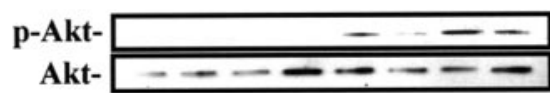

Heparitinase (0.02 U/ml) $\stackrel{(-)}{(+)} \stackrel{(-) \quad(+)}{(-)} \stackrel{(+)}{0.5} \stackrel{(-) \quad(+)}{1}$

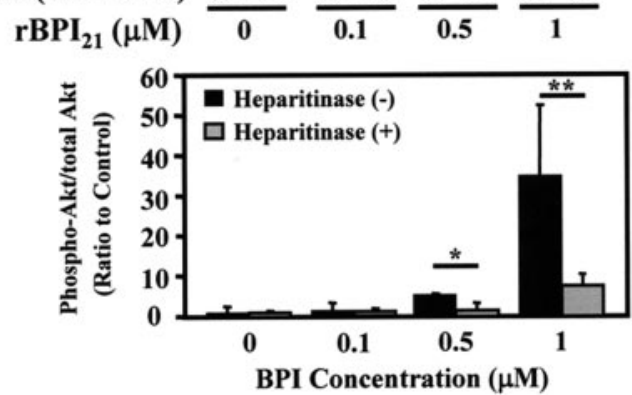

B)

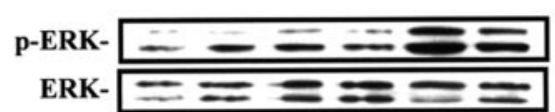

Heparitinase (0.02 U/ml)

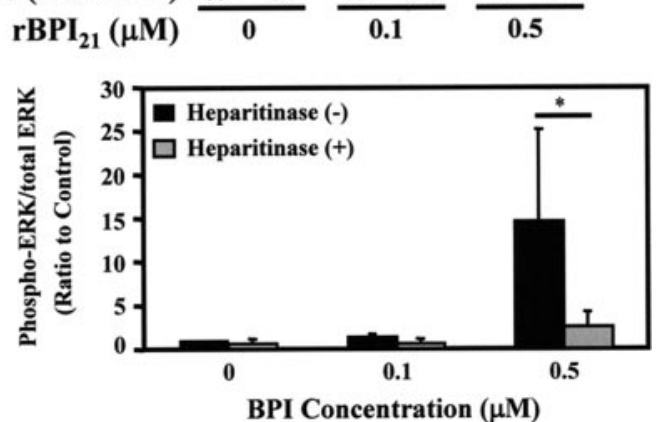

FigURE 2. Reduction of $\mathrm{rBPI}_{21}$-induced Akt and ERK phosphorylation in BRPE by heparitinase. BRPEs were treated with $0.02 \mathrm{U} / \mathrm{mL}$ heparitinase at $37^{\circ} \mathrm{C}$ for 1 hour before stimulation with $\mathrm{rBPI}_{21}$ at the concentrations shown for 10 minutes (AKT) or 30 minutes (ERK). Akt (A) and ERK (B) phosphorylation were detected by Western blot analyses and normalized with total Atk and ERK expression. Results of one experiment representative of three immunoblots are shown with densitometric quantitation (mean $\pm \mathrm{SD}$ ) from three experiments. ${ }^{*} P<0.05$; ${ }^{* *} P<$ 0.001 . 
A)

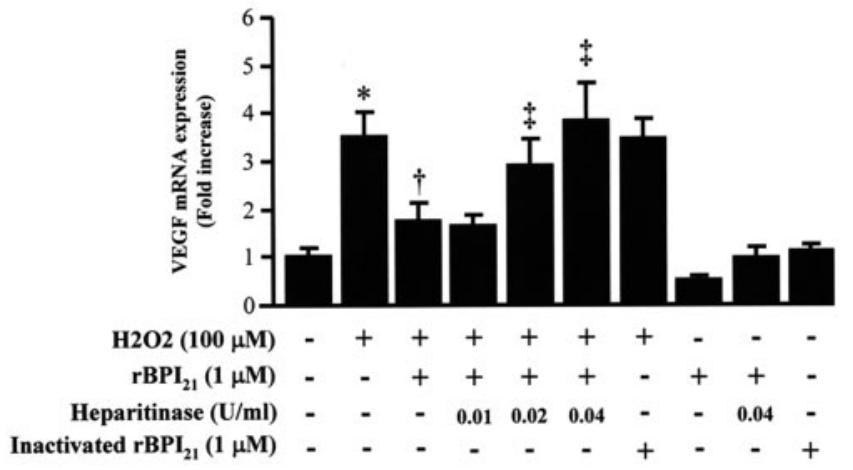

B)

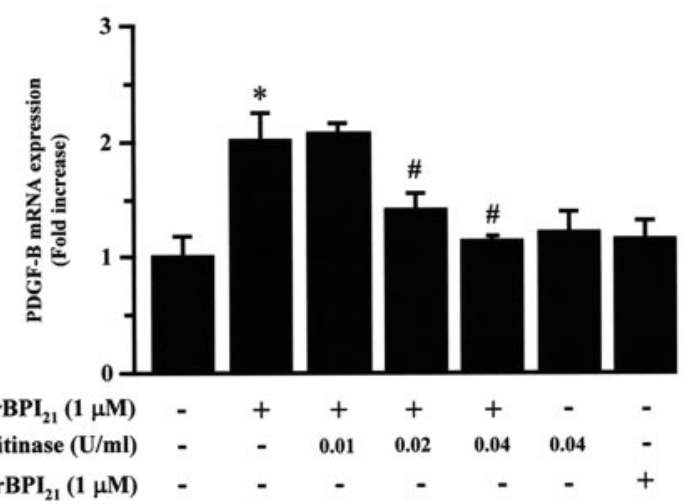

Figure 3. Modulation of VEGF and PDGF-B mRNA expression by rBPI21. BRPE cells were seeded in a six-well culture plate and treated with different concentrations of heparitinase at $37^{\circ} \mathrm{C}$ for 1 hour before the addition of $\mathrm{rBPI}_{21}$ or inactivated $\mathrm{rBPI}_{21}(1 \mu \mathrm{M})$ for 4 hours. Cells were then stimulated with $\mathrm{H}_{2} \mathrm{O}_{2}(100 \mu \mathrm{M})$ for another 4 fours. Total RNA was extracted, and VEGF (A) and PDGF-B mRNA (B) mRNA expression were evaluated by RT-PCR normalized by 185 mRNA expression. Experiments were conducted in triplicate, and data are expressed as mean $\pm \mathrm{SD} .{ }^{*} P<0.05$ versus PBS-treated cells; $\uparrow P<0.05$ versus $\mathrm{H}_{2} \mathrm{O}_{2} ; \ddagger P<0.05$ versus $\mathrm{H}_{2} \mathrm{O}_{2}+\mathrm{BPI} ; \# P<0.05$ versus $\mathrm{BPI}$.

by $50 \%$ compared with PBS-treated cells. This effect of $\mathrm{rBPI}_{21}$ was also prevented completely by heparitinase preincubation $(P<0.05)$. In contrast to VEGF, rBPI $_{21}$ stimulated mRNA expression of PDGF-B mRNA in BRPE by twofold $(P<0.05$; Fig. 3B). Preincubating BRPE with heparitinase at a concentration of 0.02 and $0.04 \mathrm{U} / \mathrm{mL}$ reduced $\mathrm{rBPI}_{21}$-induced PDGF-B mRNA expression by $51 \%$ and $91 \%(P<0.05$; Fig. 3B). Heparitinase alone had no effect on either VEGF or PDGF-B mRNA expression. Furthermore, the use of inactivated $\mathrm{rBPI}_{21}$ had no effect on preventing $\mathrm{H}_{2} \mathrm{O}_{2}$-induced VEGF mRNA expression or on increasing PDGF mRNA expression in RPE (Figs. 3A, 3B).

\section{Phosphatidylinositol-Specific Phospholipase C Prevented rBPI21 Effects on Akt Phosphorylation}

Phospholipase C (PLC) converts phosphatidylinositol to inositol triphosphate and diacylglycerol and increases the activity of protein kinase $\mathrm{C}^{22}$ In the present study, similar to heparitinase, phosphatidylinositol-specific PLC was used to cleave the GPIanchored portion of GPC4. The addition of PLC $(0.2 \mathrm{U} / \mathrm{mL})$ suppressed $\mathrm{rBPI}_{21}$-induced Akt phosphorylation by $25 \%$ and $42 \%$ at $0.5 \mu \mathrm{M}$ and $1 \mu \mathrm{M}$ rBPI21 $(P=0.03$ and $P=0.006$, respectively; Fig. 4).

\section{Blocking GPC-4 Binding Reduced rBPI21-Induced Phosphorylation of Akt}

To determine further that GPC4 was responsible for mediating $\mathrm{rBPI}_{21}$-induced Akt phosphorylation in BRPE, the effects of using neutralizing antibodies to GPC4 was studied. Incubation with several concentrations of GPC4 blocking antibody (60, 1.2 , and $0.6 \mu \mathrm{g} / \mathrm{mL}$ ) resulted in the suppression of $0.5 \mu \mathrm{M}$ $\mathrm{rBPI}_{21}$-induced Akt phosphorylation by $76.9 \%, 37.5 \%$, and $21.1 \%$, respectively (Fig. 5).

\section{Discussion}

We have recently characterized for the first time the expression of BPI and the potential biological and physiological effects related to its cellular signaling pathway in the retina in vivo and in cultured retinal cells. ${ }^{4}$ In the present study, we provided new insight on a potential mechanism related to BPI-binding protein and signaling pathway in BRPE. Initially, BPI expression was only observed in the azurophilic granules of neutrophils. ${ }^{1}$ More recently, studies have reported its expression in other cell types, such as mucosal epithelial cells of diverse origin (oral, pulmonary, and gastrointestinal mucosa) and skin follicles. ${ }^{3,23}$ Our group has reported that mRNA levels of BPI are also expressed in several cell types in the retina, including RPE, pericytes, and retinal endothelial cells. However, the specific cellular localization of BPI in the retina must be defined in detail. Nevertheless, the findings of similar concentration of BPI in human vitreous and plasma, in addition to its expression in cells not directly exposed to the external environment, suggest that BPI is synthesized in retinal tissues. ${ }^{1,2,4}$ Our previous study demonstrated that BPI can affect vascular functions and can activate Akt/MAP kinase pathways in several types of retinal cells. ${ }^{4}$ However, these results did not provide any information on the binding proteins, which can mediate the effects of BPI in retinal cells.

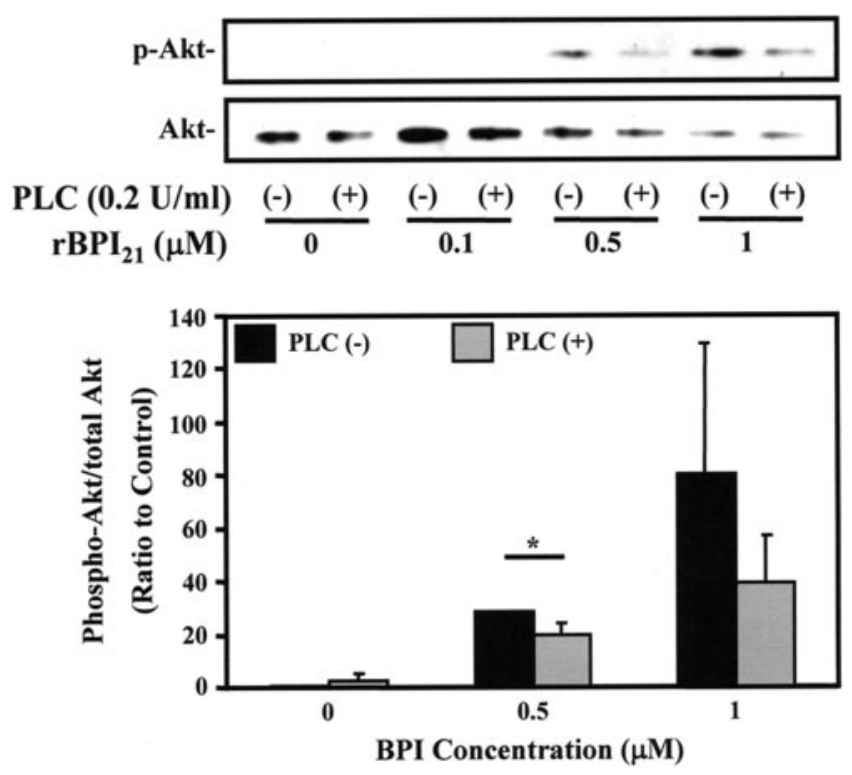

FIGURE 4. Phosphatidylinositol-specific PLC prevented rBPI21 effects on Akt phosphorylation. Cells were treated with $0.2 \mathrm{U} / \mathrm{mL}$ phosphatidylinositol-specific PLC at $37^{\circ} \mathrm{C}$ for 1 hour before stimulation with 0.5 and $1 \mu \mathrm{M} \mathrm{rBPI}_{21}$ for 15 minutes. Total Akt and phospho-Akt were detected by Western blot analyses. Results of one experiment representative of three immunoblots are shown with densitometric quantitation (mean $\pm \mathrm{SD}$ ) from three experiments. ${ }^{*} P<0.05$. 

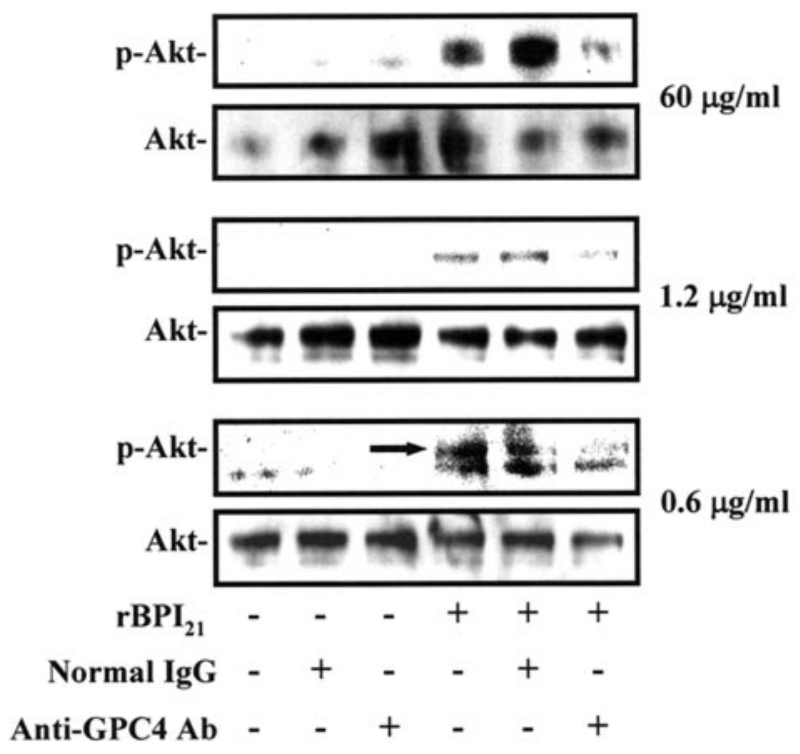

Concentration of anti-GPC4 antibody; $60 \mu \mathrm{g} / \mathrm{ml}$ (top), $1.2 \mu \mathrm{g} / \mathrm{ml}$ (middle), $0.6 \mu \mathrm{g} / \mathrm{ml}$ (bottom)

FigURE 5. Effect of GPC-4 neutralized antibody on reduction of rBPI21-induced phosphorylation of Akt. BRPE cells were treated with anti-GPC4 antibody or normal rabbit immunoglobulin at $37^{\circ} \mathrm{C}$ for 1 hour before stimulation with $0.5 \mu \mathrm{M} \mathrm{rBPI}_{21}$ for 15 minutes. Total Akt and phospho-Akt were detected by Western blot analyses. The inhibition was observed at multiple concentrations of anti-GPC antibody $(0.6-60 \mu \mathrm{g} / \mathrm{mL})$.

We have characterized some of the mechanisms by which BPI induces its various and paradoxical cellular actions in retinal EC, RPE, and pericytes. The concentrations of BPI required to achieve maximum activity in RPE and pericytes are in the micromolar range, suggesting that the receptors or binding proteins needed for BPI to mediate its actions may not be classical receptors for hormones or cytokines but may rather be more like low-affinity receptors or binding proteins for nutrients or cytoskeletal/matrix proteins. ${ }^{24,25}$ The new finding of GPC 4 as a potential cellular receptor for BPI by tandem mass spectroscopy in RPE is consistent with results of the doseresponse curves. Multiple lines of evidence suggested that GPC4 is a plausible candidate for a cell surface receptor of BPI in RPE, even though the originating membrane fractions did not exclusively contain plasma membranes. ${ }^{26}$ Structurally, GPC4 belongs to a family of cell surface heparan sulfate proteoglycans, which are anchored to the cell membrane by glycosylphosphatidylinositol and mediate many effects, especially during development. These effects include mitogenic signaling mediated by their heparan sulfate chains. ${ }^{21,27}$ The combined findings that heparitinase, phosphatidylinositol-specific phospholipase C, and anti-GPC4 antibody reduced BPI-induced signaling clearly supported the idea that GPC4 mediates the actions of BPI in RPE. These results also suggest strongly that GPC4 exerts its actions through cellular membranes because all three proteins were added extracellularly to inhibit the actions of rBPI.

The exact signaling mechanism used by GPC4 to activate ERK and Akt after binding to BPI is unclear because glypican does not contain an intracellular kinase domain. It is possible that GPC4 acts as a platform to accumulate heparin-binding growth factors such as fibroblast growth factor and hepatocyte growth factor, thus enhancing their cellular actions. ${ }^{28} \mathrm{BPI}$ might also bind to GPC4 directly to alter cell surface structures, activate PI3K/Akt or ERK pathways, and modulate VEGF and
PDGF-B mRNA expression. We have previously reported that BPI can stimulate DNA synthesis in BRPE and pericytes. ${ }^{4}$ The findings of the present study showing that BPI can increase the expression of PDGF-B mRNA levels by BPI may explain the mitogenic actions of BPI on RPE and pericyte growth. It is surprising that BPI did not have any direct effects in endothelial cells, which are reported to express GPC $4,{ }^{29}$ though endothelial cells may express other types of glypicans in addition to GPC4. According to Karihaloo et al., ${ }^{30}$ the overexpression of GPC4, but not of GPC3, induces sustained MAPK activation and renal tubular formation. In contrast, GPC3 is known to inhibit cell proliferation in a tissue-specific manner. ${ }^{31}$ Thus, other glypicans may affect the cell-specific signaling induced by BPI. The antiangiogenic actions of rBPI might have resulted from its inhibitory effects on VEGF expression in various retinal cells. This possibility was suggested by the findings that $\mathrm{rBPI}_{21}$ decreased $\mathrm{H}_{2} \mathrm{O}_{2}$-induced VEGF expression. Further studies are needed to clarify how GPC4 transduces its intracellular signal in RPE. It is also possible that GPC4 may not be the only BPI binding protein on RPE or pericytes. Clearly, more studies are needed to determine the significance of GPC4 as a receptor for $\mathrm{rBPI}_{21}$ and to determine whether GPC4 is the receptor for BPI in human RPEs and in cells other than RPE.

In this study, we have identified GPC4 as a putative BPIbinding protein related to the activation of Akt/MAP kinase pathways and biological actions of BPI. The dual effect of BPI as a mitogen for RPE and pericytes resulting in anti-VEGF actions may represent a novel therapeutic potential for the treatment of diabetic retinopathy and all related macular dysfunction.

\section{References}

1. Weiss J, Elsbach P, Olsson I, Odeberg H. Purification and characterization of a potent bactericidal and membrane active protein from the granules of human polymorphonuclear leukocytes. $\mathrm{J} \mathrm{Biol}$ Chem. 1978;253:2664-2672.

2. Shafer WM, Martin LE, Spitznagel JK. Cationic antimicrobial proteins isolated from human neutrophil granulocytes in the presence of diisopropyl fluorophosphate. Infect Immun. 1984;45:29-35.

3. Canny G, Levy O, Furuta GT, et al. Lipid mediator-induced expression of bactericidal/ permeability-increasing protein (BPI) in human mucosal epithelia. Proc Natl Acad Sci USA. 2002;99:39023907.

4. Yamagata M, Rook SL, Sassa Y, et al. Bactericidal/permeabilityincreasing protein's signaling pathways and its retinal trophic and anti-angiogenic effects. FASEB J. 2006;20:2058-2067.

5. van der Schaft DW, Toebes EA, Haseman JR, Mayo KH, Griffioen AW. Bactericidal/permeability-increasing protein (BPI) inhibits angiogenesis via induction of apoptosis in vascular endothelial cells. Blood. 2000;96:176-181.

6. Gazzano-Santoro H, Parent JB, Grinna L, et al. High-affinity binding of the bactericidal/permeability-increasing protein and a recombinant amino-terminal fragment to the lipid A region of lipopolysaccharide. Infect Immun. 1992;60:4754-4761.

7. Weiss J, Elsbach P, Shu C, et al. Human bactericidal/permeabilityincreasing protein and a recombinant $\mathrm{NH}$ 2-terminal fragment cause killing of serum-resistant Gram-negative bacteria in whole blood and inhibit tumor necrosis factor release induced by the bacteria. J Clin Invest. 1992;90:1122-1130.

8. Rauniyar RK, Suzuma K, King AL, Aiello LP, King GL. Differential effects of bactericidal/permeability-increasing protein (BPI) analogues on retinal neovascularization and retinal pericyte growth. Invest Ophthalmol Vis Sci. 2002;43:503-509.

9. Kuwabara T, Cogan DG. Retinal vascular patterns, VI: mural cells of the retinal capillaries. Arch Opbthalmol. 1963;69:492-502.

10. King GL, Suzuma K. Pigment-epithelium-derived factor-a key coordinator of retinal neuronal and vascular functions. $N$ Engl J Med. 2000;342:349-351.

11. Shima DT, Adamis AP, Ferrara N, et al. Hypoxic induction of endothelial cell growth factors in retinal cells: identification and 
characterization of vascular endothelial growth factor (VEGF) as the mitogen. Mol Med. 1995;1:182-193.

12. Betsholtz C. Role of platelet-derived growth factors in mouse development. Int J Dev Biol. 1995;39:817-825.

13. Lindahl P, Johansson BR, Leveen P, Betsholtz C. Pericyte loss and microaneurysm formation in PDGF-B-deficient mice. Science. 1997;277:242-245.

14. Wilkinson-Berka JL, Babic S, De Gooyer T, et al. Inhibition of platelet-derived growth factor promotes pericyte loss and angiogenesis in ischemic retinopathy. Am J Pathol. 2004;164:12631273.

15. King GL, Goodman AD, Buzney S, Moses A, Kahn CR. Receptors and growth-promoting effects of insulin and insulinlike growth factors on cells from bovine retinal capillaries and aorta. J Clin Invest. 1985;75:1028-1036.

16. King GL, Berman AB, Bonner-Weir S, Carson MP. Regulation of vascular permeability in cell culture. Diabetes. 1987;36:14601467.

17. Little RG, Kelner DN, Lim E, Burke DJ, Conlon PJ. Functional domains of recombinant bactericidal/permeability increasing protein (rBPI23). J Biol Chem. 1994;269:1865-1872.

18. Ford-Perriss M, Turner K, Guimond S, et al. Localisation of specific heparan sulfate proteoglycans during the proliferative phase of brain development. Dev Dyn. 2003;227:170-184.

19. Watanabe K, Yamada H, Yamaguchi Y. K-glypican: a novel GPIanchored heparan sulfate proteoglycan that is highly expressed in developing brain and kidney. J Cell Biol. 1995;130:1207-1218.

20. Hagihara K, Watanabe $\mathrm{K}$, Chun J, Yamaguchi Y. Glypican- 4 is an FGF2-binding heparan sulfate proteoglycan expressed in neural precursor cells. Dev Dyn. 2000;219:353-367.
21. Filmus J, Selleck SB. Glypicans: proteoglycans with a surprise. J Clin Invest. 2001;108:497-501.

22. O'Brian CA, Ward NE. Biology of the protein kinase C family. Cancer Metastasis Rev. 1989;8:199-214.

23. Takahashi M, Horiuchi Y, Tezuka T. Presence of bactericidal/ permeability-increasing protein in human and rat skin. Exp Dermatol. 2004;13:55-60.

24. Palacin M, Estevez R, Bertran J, Zorzano A. Molecular biology of mammalian plasma membrane amino acid transporters. Physiol Rev. 1998;78:969-1054.

25. Levine KB, Cloherty EK, Hamill S, Carruthers A. Molecular determinants of sugar transport regulation by ATP. Biochemistry. 2002; 41:12629-12638.

26. Filmus J. The contribution of in vivo manipulation of gene expression to the understanding of the function of glypicans. Glycoconj J. 2002;19:319-323.

27. Fransson LA, Belting M, Cheng F, Jonsson M, Mani K, Sandgren S. Novel aspects of glypican glycobiology. Cell Mol Life Sci. 2004;61: 1016-1024.

28. Bernfield M, Gotte M, Park PW, et al. Functions of cell surface heparan sulfate proteoglycans. Annu Rev Biochem. 1999;68:729777.

29. Karumanchi SA, Jha V, Ramchandran R, et al. Cell surface glypicans are low-affinity endostatin receptors. Mol Cell. 2001;7:811-822.

30. Karihaloo A, Kale S, Rosenblum ND, Cantley LG. Hepatocyte growth factor-mediated renal epithelial branching morphogenesis is regulated by glypican-4 expression. Mol Cell Biol. 2004;24: 8745-8752.

31. Midorikawa $\mathrm{Y}$, Ishikawa $\mathrm{S}$, Iwanari $\mathrm{H}$, et al. Glypican-3, overexpressed in hepatocellular carcinoma, modulates FGF2 and BMP-7 signaling. Int J Cancer. 2003;103:455- 465. 